\title{
ANALIZA MOTIVACIJE, ZADOVOLJSTVA POSLOM I RADNOG UČINKA ZAPOSLENIKA NA PRIMJERU ODABRANOG PODUZEĆA
}

\author{
Davorka Prahin, struč. spec. oec. \\ Podzemno skladište plina d.o.o. \\ Telefon: +385 (0) 99/ 3124 201, e-mail: davorka.prahin@psp.hr \\ Dr. sc. Ivica Katavić, prof. v. š. u trajnom zvanju \\ Europska poslovna škola Zagreb \\ Selska 119, Zagreb \\ Telefon: +385 (0)99/ 3695 585, e-mail: ivica.katavic@ebus.hr
}

\section{SAŽETAK}

Ljudski resursi su nedvojbeno ključni resursi svakog poduzeća te imaju bitnu ulogu u postizanju ciljeva i uspješnosti poduzeća u cjelini. U tom kontekstu su motivacija, zadovoljstvo poslom i radni učinak prepoznati kao ključni pojmovi vezani uz ljudske resurse. lako su istraživanja pokazala da postoji pozitivna korelacija između motivacije zaposlenika i radne uspješnosti, još uvijek nije dovoljno jasno koji faktori motivacije u kolikoj mjeri doprinose radnoj uspješnosti. Stoga je glavni cilj istraživanja bio ispitati koji faktori motivacije i zadovoljstva poslom najviše doprinose radnoj uspješnosti te u kolikoj mjeri to čine, kao i procijeniti usklađenost motivacijskog sustava sa željama zaposlenika odabranog poduzeća. U svrhu ostvarenja glavnog cilja provedeno je istraživanje na populaciji zaposlenika odabranog poduzeća putem anketnog upitnika i intervjua. Rezultati istraživanja pokazali su da su zaposlenicima najveći faktori motivacije plaća i sigurnost posla, a među elementima posla najbolje su ocijenili redovitost isplate plaće, radno vrijeme te stalnost zaposlenja. U samoprocjeni radnog učinka zaposlenici su najbolje ocijenili svoju pouzdanost i prilagodljivost. Utvrđeno je da motivacijski sustav nije u potpunosti usklađen ni sa željama zaposlenika ni sa željama menadžmenta te da su u području materijalnog i nematerijalnog nagrađivanja, procesu napredovanja i na području edukacije moguće dorade i unaprjeđenja kako bi cjelokupni sustav u najvećoj mogućoj mjeri postao usklađen te učinkovit.

Ključne riječi: motivacija, zadovoljstvo poslom, faktori motivacije, faktori zadovoljstva, radni učinak 


\section{UVOD}

Motivacija je pojam koji se izučava u mnogim znanstvenim krugovima te ga se pokušava definirati na jedinstven, univerzalno primjenjiv način. Polazno stajalište je da je ponašanje ljudi određeno ciljevima koje žele postići, a motivaciju možemo shvatiti kao ono nešto u čovjeku što ga usmjerava i potiče njegovo ponašanje prema ostvarenju cilja. Tablica 1. sumira nekoliko različitih definicija motivacije.

Tablica 1. Definiranje pojma motivacije

\begin{tabular}{ll}
\hline Autori & Definicije motivacije \\
\hline Bahtijarević Šiber (1999) & $\begin{array}{l}\text { Zajednički pojam za sve unutarnje faktore koji konsolidiraju intelektualnu i } \\
\text { fižku energiju, iniciraju i organiziraju individualne aktivnosti, usmjeravaju } \\
\text { ponašanje te mu određuju smjer, intenzitet i trajanje. }\end{array}$ \\
\hline Buble (2006) & Svaki utjecaj koji izaziva, usmjerava i održava ciljno ponašanje ljudi. \\
\hline Hrvatska enciklopedija & $\begin{array}{l}\text { Psihički proces koji nas potiče na mentalne ili tjelesne aktivnosti, i „iznutra“ } \\
\text { djeluje na naše ponašanje. }\end{array}$ \\
\hline Leksikon psihologije & $\begin{array}{l}\text { Ponašanje usmjereno prema nekom cilju koji pobuđuje potrebe izazvane u } \\
\text { čovjeku, a razlog ponašanja je zadovoljenje potreba. }\end{array}$ \\
\hline Tudor (2010) & $\begin{array}{l}\text { Unutarnji nagon koji tjera pojedinca da se ponaša na način koji će mu } \\
\text { omogućiti zadovoljenje njegovih potreba, odnosno ostvarenje njegovih } \\
\text { ciljeva. }\end{array}$ \\
\hline
\end{tabular}

Izvor: Rad autora

$\mathrm{Na}$ individualnu motivaciju zaposlenika unutar organizacije, odnosno poduzeća djeluje mnoštvo faktora, a mogu se svrstati u tri kategorije: individualne osobine, karakteristike posla koji pojedinac obavlja te karakteristike organizacije, odnosno radne situacije i šira društvena okolina (Bahtijarević Šiber, 1999).

Individualne karakteristike odnose se na očekivanja, potrebe, stavove, preferencije zaposlenika i sl. Valja imati na umu da se ove karakteristike razlikuju kod svakog zaposlenika te da je potrebna vještina kako bi se na optimalan način njima upravljalo.

Karakteristike posla odnose se na raznolikost, zanimljivost, zahtjevnost, autonomiju, povratnu informaciju i sl. Menadžeri prilikom oblikovanja posla te prilikom dodjele posla zaposlenicima trebaju postići sklad između karakteristika zaposlenika i karakteristika posla koji dodjeljuju pojedinom zaposleniku.

Karakteristike organizacije odnose se na neposrednu radnu okolinu (suradnike, menadžere, radne uvjete i sl.) te na organizacijsku praksu (procedure, načine rukovođenja, sustav nagrađivanja, organizacijsku kulturu i sl.).

Menadžeri moraju kod kreiranja motivacijskog sustava uzeti u obzir sve navedene faktore kako bi prilagodili sustav, kako zaposlenicima tako i poduzeću, i postigli idealno rješenje unutar zadanih okolnosti. 
Strategije motiviranja u poduzećima mogu se podijeliti u dvije osnovne grupe: materijalne i nematerijalne strategije. Materijalne strategije nagrađivanja u prvom redu se odnose na „osiguranje i poboljšanje materijalnog položaja zaposlenih i financijskih kompenzacija za rad“ (Bahtijarević Šiber, 1999, str. 613). U Tablici 2. prikazana je klasifikacija ukupnih materijalnih tj. financijskih kompenzacija zaposlenih.

\section{Tablica 2. Klasifikacija materijalnih kompenzacija zaposlenih}

\begin{tabular}{|c|c|c|c|}
\hline & & $\begin{array}{l}\text { IZRAVNE MATERIJALNE } \\
\text { KOMPENZACIJE }\end{array}$ & $\begin{array}{l}\text { NEIZRAVNE MATERIJALNE } \\
\text { KOMPENZACIJE }\end{array}$ \\
\hline \multirow[b]{2}{*}{ RAZINA } & pojedinac & $\begin{array}{l}\text { - Plaća } \\
\text { - Bonusi i poticaji } \\
\text { - Naknada za inovacije i poboljšanja } \\
\text { - Naknada za širenje znanja i } \\
\text { fleksibilnost } \\
\text { - Ostali poticaji (bonusi) }\end{array}$ & $\begin{array}{l}\text { - Stipendije i školarine } \\
\text { - Studijska putovanja } \\
\text { - Specijalizacije } \\
\text { - Plaćene odsutnosti i slobodni dani } \\
\text { - Automobil kompanije } \\
\text { - Menadžerske beneficije }\end{array}$ \\
\hline & poduzeće & $\begin{array}{l}\text { - Bonusi vezani uz rezultate i dobitak } \\
\text { organizacijske jedinice ili poduzeća } \\
\text { - Udio u profitu } \\
\text { - Udio u vlasništvu (distribucija } \\
\text { dionica) }\end{array}$ & $\begin{array}{l}\text { - Mirovinsko osiguranje } \\
\text { - Zdravstvena zaštita } \\
\text { - Životno i druga osiguranja } \\
\text { - Naknade za nezaposlenost } \\
\text { - Obrazovanje } \\
\text { - Godišnji odmori } \\
\text { - „Božićnica“ i drugo } \\
\text { - Skrb o djeci i starima }\end{array}$ \\
\hline
\end{tabular}

Izvor: Rad autora prema Bahtijarević Šiber, (1999). Management ljudskih potencijala. Zagreb: Golden marketing, str. 614

Osim materijalnih kompenzacija, u praksi modernih poduzeća, u svrhu poticanja motivacije za rad i uspješnost, razvijene su i brojne nematerijalne strategije motiviranja. Naime, uočeno je da ljudi svojim radom žele zadovoljiti više raznolikih potreba, a ne samo one egzistencijalne prirode. Putem nematerijalnih strategija motiviranja, koje su u pravilu nadogradnja materijalnih kompenzacija, poduzeća nastoje pridobiti i zadržati čim kvalitetnije ljudske resurse (Bahtijarević Šiber, 1999). Pregled najčešće korištenih nematerijalnih strategija prikazan je na Slici 1. 


\section{Slika 1. Nematerijalne strategije motiviranja zaposlenih}

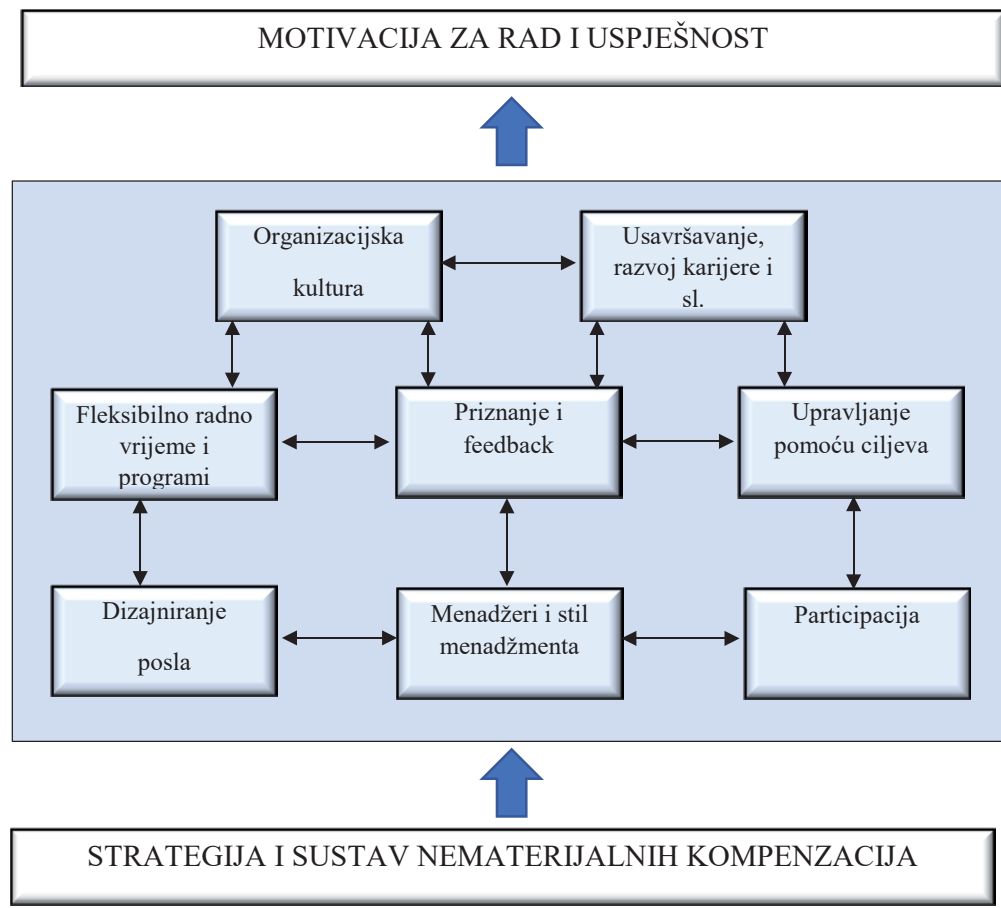

Izvor: Rad autora prema Bahtijarević Šiber (1999). Management ljudskih potencijala. Zagreb: Golden marketing, str. 668

Motivacija za rad, osim temeljnim potrebama, koje se zadovoljavaju strategijama i sustavom materijalnog motiviranja, nadograđuje se nematerijalnim strategijama motiviranja. U tu grupu spadaju dizajniranje posla, menadžeri i njihov stil, fleksibilno radno vrijeme, mogućnost usavršavanja i daljnjeg razvoja, organizacijska kultura, priznanje i povratna informacija, organizacijska kultura, upravljanje pomoću ciljeva i participacija zaposlenika. Navedene strategije najčešće financijski ne opterećuju poduzeće, a mogu ostvariti pozitivne efekte na motivaciju zaposlenika. Pri odabiru nematerijalnih strategija vrlo je važno dobro poznavati ljudske resurse kojima poduzeće raspolaže, shvatiti njihove potrebe i želje te sustav motiviranja prilagoditi zaposlenicima.

Budući da većina zaposlenih na poslu provodi 40 sati tjedno, posao i okruženje posla čine izuzetno bitan dio njihovog života. Zadovoljstvo poslom tako postaje važna značajka općenitog zadovoljstva životom (Brown i Mclntosh, 2003). Zadovoljstvo poslom može se definirati kao „pozitivan stav o vlastitom poslu koji proizlazi iz karakteristika tog posla“ (Robbins i Judge, 2009, str. 78). Kako bi se proaktivno djelovalo u svrhu povećanja zadovoljstva poslom, bitno je poznavati čimbenike koji utječu na formiranje stava pojedinca po pitanju zadovoljstva poslom. Istraživanja su pokazala da se čimbenici zadovoljstva poslom mogu grupirati u dvije kategorije, a to su: organizacijski čimbenici zadovoljstva poslom i osobni čimbenici zadovoljstva poslom (Greenberg i Baron, 1998). Dok Tablica 3. prikazuje najznačajnije organizacijske čimbenike zadovoljstva poslom, Tablica 4. prikazuje najznačajnije osobne čimbenike zadovoljstva poslom. 


\section{Tablica 3. Najznačajniji organizacijski čimbenici zadovoljstava poslom}

\begin{tabular}{ll}
\hline Organizacijski čimbenici & Zadovoljstvo poslom \\
\hline Posao sam po sebi & $\begin{array}{l}\text { Zaposlenici su zadovoljniji ako obavljaju posao koji je izazovniji, umjesto da } \\
\text { obavljaju neki jednostavan rutinski posao. Izazovnijim se smatra posao koji } \\
\text { podrazumijeva raznovrsne zadatke, posao koji daje određenu dozu slobode } \\
\text { kod obavljanja i omogućava povratnu informaciju o kvaliteti obavljenog } \\
\text { posla. }\end{array}$ \\
\hline Sustav nagrađivanja & $\begin{array}{l}\text { lako je visina plaće bitan čimbenik zadovoljstva, zaposlenici će biti } \\
\text { zadovoljniji ako sustav nagrađivanja percipiraju kao pravedan, odnosno ako }\end{array}$ \\
\hline Radni uvjeti & $\begin{array}{l}\text { Zaposlenima su vrlo važni radni uvjeti i ako su oni bolji, i radni učinak će biti } \\
\text { bolji. Na taj način će se postići i veće zadovoljstvo zaposlenika. }\end{array}$ \\
\hline Kolege / suradnici & $\begin{array}{l}\text { Zaposleni su zadovoljniji poslom ako u poduzeću vlada harmonija među } \\
\text { kolegama i suradnicima. Također im je važan i odnos s neposrednim } \\
\text { rukovoditeljem, od kojeg očekuju korektan odnos, pohvalu za uloženi napor } \\
\text { i trud. }\end{array}$ \\
\hline Organizacijska struktura & $\begin{array}{l}\text { Zaposleni su zadovoljniji ako struktura nije stroga i centralizirana, već im daje } \\
\text { određenu mogućnost participacije u odlučivanju, odnosno ako je struktura } \\
\text { jasna, poznata i stabilna. }\end{array}$ \\
\hline
\end{tabular}

Izvor: Rad autora prema Greenberg J., Baron R. (1998). Ponašanje ljudi u organizacijama. Beograd: Želnid

\section{Tablica 4. Najznačajniji osobni čimbenici zadovoljstava poslom}

\begin{tabular}{|c|c|}
\hline Osobni čimbenici & Zadovoljstvo poslom \\
\hline $\begin{array}{l}\text { Sklad između osobnih } \\
\text { interesa i posla }\end{array}$ & $\begin{array}{l}\text { Poslom su zadovoljniji zaposlenici čije osobne kvalifikacije i preferencije bolje } \\
\text { odgovaraju potrebama i uvjetima radnog mjesta. }\end{array}$ \\
\hline Radni staž i starost & $\begin{array}{l}\text { Zaposlenici tijekom radnog staža stječu znanja i iskustvo pa su stariji } \\
\text { zaposlenici u pravilu kvalitetniji u obavljanju svog posla te bivaju češće } \\
\text { nagrađeni ili pohvaljeni za ostvarene rezultate. To za posljedicu ima veće } \\
\text { zadovoljstvo poslom. }\end{array}$ \\
\hline Pozicija i status & $\begin{array}{l}\text { U pravilu su više pozicionirani zaposlenici zadovoljniji od niže pozicioniranih } \\
\text { kolega jer im upravo pozicija i status donose određene beneficije (bolju plaću, } \\
\text { ugled, samostalnost, mogućnost dodatne edukacije i usavršavanja i sl.). }\end{array}$ \\
\hline $\begin{array}{l}\text { Ukupno zadovoljstvo } \\
\text { životom }\end{array}$ & $\begin{array}{l}\text { Zaposlenici koji su zadovoljni poslom, a budući da je posao važan segment } \\
\text { ljudskog života, ocjenjuju i ukupno zadovoljstvo životom višim ocjenama. }\end{array}$ \\
\hline
\end{tabular}

Izvor: Rad autora prema Greenberg, Baron (1998). Ponašanje ljudi u organizacijama. Beograd: Želnid

Valja napomenuti da su organizacijski čimbenici ustvari vanjski čimbenici te zaposlenici ne mogu izravno utjecati na njih. S druge strane, osobni čimbenici su u izravnoj korelaciji s osobnošću pojedinog zaposlenika i individualne su naravi.

Trajno nezadovoljstvo poslom izaziva stres, a on izravno utječe na pojavu pojačanog apsentizma i fluktuacije zaposlenika. Stoga je poslodavcima informacija o razini (ne)zadovoljstva njihovih zaposlenika vrlo bitna. 
Postoje razni načini kako ispitati zadovoljstvo poslom. Jedan od najčešće primjenjivanih načina jest identifikacija bitnih elemenata posla i prikupljanje mišljenja zaposlenika o njihovoj ocjeni pojedinih elemenata (priroda posla, suradnici, nadređeni, mogućnost napredovanja, visina plaće, redovitost isplate plaće, radni uvjeti, stalnost zaposlenja, radno vrijeme, obuka i sl.). Pri tome se ocjena obično kreće u rasponu od 1 do 5 . Na kraju se računa prosječna ocjena zadovoljstva poslom. Budući da se radi o osobnim ocjenama elemenata posla zaposlenika, valja imati na umu da je ocjena zadovoljstva poslom izrazito subjektivna kategorija, no ujedno i najbolji pokazatelj nivoa zadovoljstva poslom u cjelini. Na taj način poduzeće dolazi do vrijednih informacija koje mogu biti podloga za razvoj i unaprjeđenje pojedinih elemenata posla te podizanja ukupnog zadovoljstva poslom u poduzeću.

Nadalje, dosad provedena istraživanja odnosa zadovoljstva poslom i radnog učinka čest su predmet rasprava među psiholozima koji se bave ovim područjem. Početnim istraživanjima (Brayfield i Crocket, 1955; Locke, 1976) osporavano je zadovoljstvo poslom kao relevantnim prediktorom radne uspješnosti. No, danas postoje brojna istraživanja koja pokazuju da postoji čvrsta veza između općeg zadovoljstva poslom i opće radne uspješnosti (npr. laffaldano i Muchinsky, 1985.; Petty, McGee i Cavender, 1984.; Judge i sur., 2001.) Pri sumiranju rezultata istraživanja odnosa zadovoljstva poslom i radnog učinka valja imati na umu da čitav niz drugih čimbenika, kao što su uspješnost poduzeća, zahtjevnost i složenost posla, vrsta djelatnosti, organizacijski faktori, osobne karakteristike zaposlenika, može utjecati na taj odnos.

Evaluaciju radnog učinka zaposlenika trebalo bi provoditi kontinuirano kako bi se moglo, ovisno o ocjeni, usmjeriti ponašanje i rezultate rada. Također, ocjenjivanje se ne smije najaviti jer bi to moglo potaknuti zaposlenike da promijene svoje uobičajeno ponašanje pa bi ocjena učinkovitosti bila nerealna i neobjektivna. Kroz aktivnosti evaluacije radnog učinka može se postići visok stupanj zadovoljstva i motiviranosti zaposlenih i menadžera te upravljati uspješnošću i razvojem organizacije (Rahimić, 2010, str. 242). Pored navedenih prednosti, Obradović, Samardžija i Jandrić (2015) smatraju da je vrednovanje radnog učinka važan dio upravljanja ljudskim potencijalima te da na taj način organizacija stvara konkurentsku prednost u modernom poslovnom okruženju.

lako su istraživanja pokazala da postoji pozitivna korelacija između motivacije zaposlenika i radne uspješnosti (Abbah, 2014), još uvijek nije dovoljno jasno koji faktori motivacije i u kolikoj mjeri doprinose radnoj uspješnosti. Stoga je predmet istraživanja ovog rada analiza pojedinih faktora motivacije i zadovoljstva poslom i radne uspješnosti zaposlenika.

Motivacija i zadovoljstvo u kontekstu posla su dva pojma koja se često poistovjećuju, no potrebno je naglasiti da postoji bitna razlika među njima. „Motivacija se odnosi na žudnju i napor za zadovoljenjem želja i ciljeva, a zadovoljstvo se odnosi na ispunjenje koje osjećamo zbog zadovoljenja želje." (Brnad i sur., 2016, str.111). Prema Bubli (2006), postoji realna mogućnost da su zaposlenici u isto vrijeme motivirani i nezadovoljni ili obrnuto, kao i druge kombinacije odnosa zadovoljstva i motivacije. To nameće potrebu istražiti koji su to faktori koji utječu na motivaciju odnosno zadovoljstvo zaposlenika, a kako bi se sustav motiviranja u poduzeću u najvećoj mogućoj mjeri uskladio sa željama zaposlenika. Upravo zbog svega navedenog, kao predmet istraživanja, nametnuo se utjecaj pojedinih faktora motivacije, kao i elemenata posla koji imaju utjecaj na zadovoljstvo i na radni učinak zaposlenika. 
lako su istraživanja pokazala da postoji pozitivna korelacija između motivacije zaposlenika i radne uspješnosti (Abbah, 2014), još uvijek nije dovoljno jasno koji faktori motivacije i u kolikoj mjeri doprinose radnoj uspješnosti. Stoga je predmet istraživanja ovog rada analiza pojedinih faktora motivacije i zadovoljstva poslom i radne uspješnosti zaposlenika u odabranom poduzeću koje se bavi energetskom djelatnošću. Predmetno poduzeće trenutno ima više od 250 zaposlenih.

Glavni cilj ovog istraživanja je utvrditi koji faktori motivacije i zadovoljstva poslom najviše doprinose radnoj uspješnosti, u kolikoj mjeri to čine te procijeniti usklađenost motivacijskog sustava sa željama zaposlenika odabranog poduzeća.

Pomoćni ciljevi istraživanja su:

C1. Utvrditi razinu motiviranosti i zadovoljstva poslom zaposlenika odabranog poduzeća koristeći Herzbergovu dvofaktorsku teoriju.

C2. Procijeniti usklađenost motivacijskog sustava odabranog poduzeća sa željama zaposlenika.

Sljedeća istraživačka pitanja su usmjerila istraživanja:

IP 1. Kolika je razina motiviranosti i zadovoljstva poslom zaposlenika odabranog poduzeća?

IP 2. Je li i koliko je usklađen motivacijski sustav odabranog poduzeća sa željama zaposlenika?

\section{METODOLOGIJA ISTRAŽIVANJA}

Sukladno definiranim ciljevima istraživanja provedeno je kvantitativno i kvalitativno istraživanje. Instrument za kvantitativno istraživanje je anketni upitnik proveden putem alata Google Forms, a instrument za kvalitativno istraživanje su polustrukturirani intervjui.

\subsection{Istraživačke metode i dizajn}

U ovom radu korišteni su primarni i sekundarni izvori podataka i informacija. Podaci iz primarnih izvora prikupljeni su metodom anketiranja i polustrukturiranim intervjuima. Anketa je podijeljena u četiri dijela. U uvodnom dijelu prikupljaju se demografski podaci, u drugom dijelu ispituje se razina motiviranosti po pojedinim faktorima, u trećem dijelu ispituju se stavovi ispitanika u odnosu na zadovoljstvo pojedinim elementima rada, a u četvrtom dijelu zatražena je samoprocjena radnog učinka. Sekundarni podaci prikupljeni su iz relevantne literature i dokumentacije poduzeća.

\subsection{Populacija i uzorkovanje}

Ukupni broj zaposlenih u promatranom poduzeću je 270. Ciljna populacija za anketiranje su zaposlenici odabranog poduzeća, a veličina uzorka je 100 ( $N=100)$. Uzorkovanje je provedeno slučajnim odabirom ispitanika različitih skupina s obzirom na dob, spol, stručnu spremu i vrstu poslova koje obavljaju. Populacija za intervjue su relevantni menadžeri različitih hijerarhijskih razina organizacijskih jedinica, a veličina uzorka je $8(\mathrm{~N}=8)$. 


\subsection{Prikupljanje i analiza podataka}

Prikupljanje podataka provedeno je u razdoblju od 30. travnja do 20. svibnja 2021. godine. Analiza podataka provedena je od 21. svibnja do 4. lipnja 2021. godine. Obilježja su svrstana u cjeline (grupe) podataka te je ispitana frekvencija svakog pojedinog faktora.

Vezano uz demografske podatke, ispitana su sljedeća obilježja: dob, spol, stručna sprema i ukupne godine radnog staža. $U$ dijelu koji se odnosi na motivaciju zaposlenika ispitana je razina utjecaja na ukupnu motivaciju pojedinih faktora motivacije, a koji su: politika poduzeća, plaća, beneficije, sigurnost posla, menadžeri, radni uvjeti, mogućnost priznanja i napredovanja, dodijeljena odgovornost, postignuće i uspjeh te izazovan posao. U dijelu koji se odnosi na zadovoljstvo radom zaposlenika ispitana je razina zadovoljstva pojedinim elementima posla (prirodom posla, suradnicima, nadređenima, mogućnošću napredovanja, visinom plaće, redovitošću isplate plaće, radnim uvjetima, stalnošću zaposlenja, radnim vremenom i obukom) te opće zadovoljstvo na radu. U dijelu koji se odnosi na radni učinak od zaposlenika je zatražena samoprocjena sljedećih elemenata radnog učinka: količina posla, kvaliteta rada, pouzdanost, inicijativa, prilagodljivost i sudjelovanje.

Putem polustrukturiranih intervjua s menadžerima različitih hijerarhijskih razina organizacijskih jedinica prikupljene su dodatne informacije o sustavu motivacije koji je u primjeni u odabranom poduzeću, njihova ocjena učinkovitosti sustava te prijedlozi za unapređenje, kao i njihova ocjena radnog učinka zaposlenika kojima rukovode. Ujedno su ispitani razina educiranosti menadžera u području rukovođenja i motivacije te njihovi prijedlozi za poboljšanje.

\section{REZULTATI ISTRAŽIVANJA I RASPRAVA}

Ispitanici su putem ankete pozvani da ocjenom od 1 do 5 vrednuju u kojoj mjeri ih pojedini faktori motiviraju na rad u organizaciji u kojoj su zaposleni. Ispitivani faktori motivacije temelje se na konceptu Herzbergove dvofaktorske teorije motivacije. U higijenike spadaju radni uvjeti, menadžeri, sigurnost posla, plaća, beneficije, politika poduzeća, a u motivatore izazovan posao, postignuće, uspjeh, odgovornost, mogućnost razvoja, priznanje i mogućnost napredovanja.

Ocjene ispitanika imaju sljedeće značenje: 1 - uopće ne motiviraju, 2 - slabo motiviraju, 3 - srednje motiviraju, 4 - jako motiviraju i 5 - u potpunosti motiviraju. Na Grafikonu 1. dan je prikaz pojedinih faktora motivacije i ocjena ispitanika. 


\section{Grafikon 1. Motivacija zaposlenika prema faktorima motivacije}

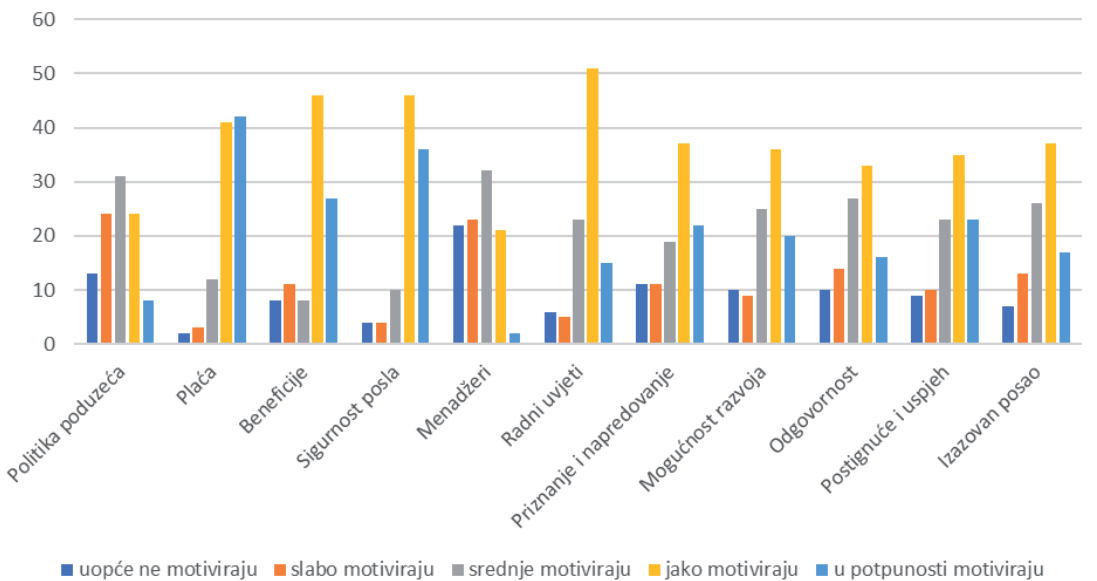

Izvor: Rad autora

Raspodjela ocjena koja je prikazana na Grafikonu 1. ukazuje da higijenike - plaću, beneficije i sigurnost posla - ispitanici ocjenjuju kao vrlo jake motivatore, dok politiku poduzeća i menadžere smatraju manje važnima. Što se tiče motivatora priznanje i napredovanje, mogućnost razvoja, odgovornost, postignuće i uspjeh i izazovan posao, ispitanici ih ocjenjuju podjednako važnima.

U svrhu daljnje evaluacije i potvrde mišljenja kreiranog na temelju podataka i grafičkog prikaza raspodjele rezultata, izračunata je prosječna ocjena svakog pojedinog faktora motivacije ovog istraživanja. S obzirom na pandemiju i općenitu nesigurnost poslovanja te ukupan pad gospodarstva, očekivano je da će zaposlenici sigurnost posla i plaću istaknuti kao najsnažnije motivatore. Najvišu prosječnu ocjenu dobio je faktor plaća $(4,18)$, slijede sigurnost posla $(4,06)$, beneficije $(3,73)$ i radni uvjeti $(3,64)$. Najmanje prepoznati kao motivatori su menadžeri $(2,58)$ i politika poduzeća $(2,90)$. U grupu srednje bitnih motivatora ispitanici su svrstali postignuće i uspjeh $(3,53)$, priznanje i napredovanje $(3,48)$, mogućnost razvoja $(3,47)$, izazovan posao $(3,44)$ i odgovornost $(3,31)$.

Menadžeri i politika poduzeća su najslabije prepoznati kao motivatori. Odgovor zašto su menadžeri ocijenjeni tako niskom ocjenom krije se u činjenici da menadžeri u promatranom poduzeću uglavnom nisu educirani za poslove rukovođenja, kao niti o metodama motivacije. Ne poznaju u dovoljnoj mjeri tehnike i metode upravljanja ljudskim resursima ni motiviranja. Stoga se njihov stil rukovođenja svodi isključivo na osobne karakteristike.

Politika poduzeća je također vrlo slab motivator jer zaposlenici nisu u dovoljnoj mjeri ni na adekvatan način informirani o toj tematici. Dodatan razlog je i u činjenici da je promatrano poduzeće u državnom vlasništvu i spada u reguliranu djelatnost pa samim time nije u potpunosti slobodno samostalno kreirati svoju politiku, nego su mnoge bitne odrednice unaprijed determinirane i dirigirane. Pregled prosječnih ocjena faktora motivacije daje se u Tablici 5. 
Tablica 5. Prosječna ocjena faktora motivacije

\begin{tabular}{|lc|}
\hline Faktor motivacije & Prosječna ocjena \\
\hline Politika poduzeća & 2,90 \\
\hline Plaća & 4,18 \\
\hline Beneficije & 3,73 \\
\hline Sigurnost posla & 4,06 \\
\hline Menadžeri & 2,58 \\
\hline Radni uvjeti & 3,64 \\
\hline Priznanje i napredovanje & 3,48 \\
\hline Mogućnost razvoja & 3,47 \\
\hline Odgovornost & 3,31 \\
\hline Postignuće i uspjeh & 3,53 \\
\hline Izazovan posao & 3,44 \\
\hline
\end{tabular}

Izvor: Rad autora

U nastavku ankete ispitana je razina zadovoljstva pojedinim elementima posla. Elementi posla određeni su na način da su u razmatranje uzeti elementi koji su prepoznati kao relevantni za poduzeće u kojem se vrši istraživanje. Tako su ispitani sljedeći elementi posla: priroda posla, suradnici, nadređeni, mogućnost napredovanja, visina plaće, redovitost isplate plaće, radni uvjeti, stalnost zaposlenja, radno vrijeme, obuka te opće zadovoljstvo na radu.

Raspon ocjena je od 1 do 5, pri čemu ocjene imaju sljedeće značenje: 1 - vrlo nezadovoljan, 2 - nezadovoljan, 3 - niti nezadovoljan niti zadovoljan, 4 - zadovoljan i 5 - vrlo zadovoljan. Na Grafikonu 2. prikazani su rezultati istraživanja zadovoljstva pojedinim elementima posla.

\section{Grafikon 2. Zadovoljstvo elementima posla}

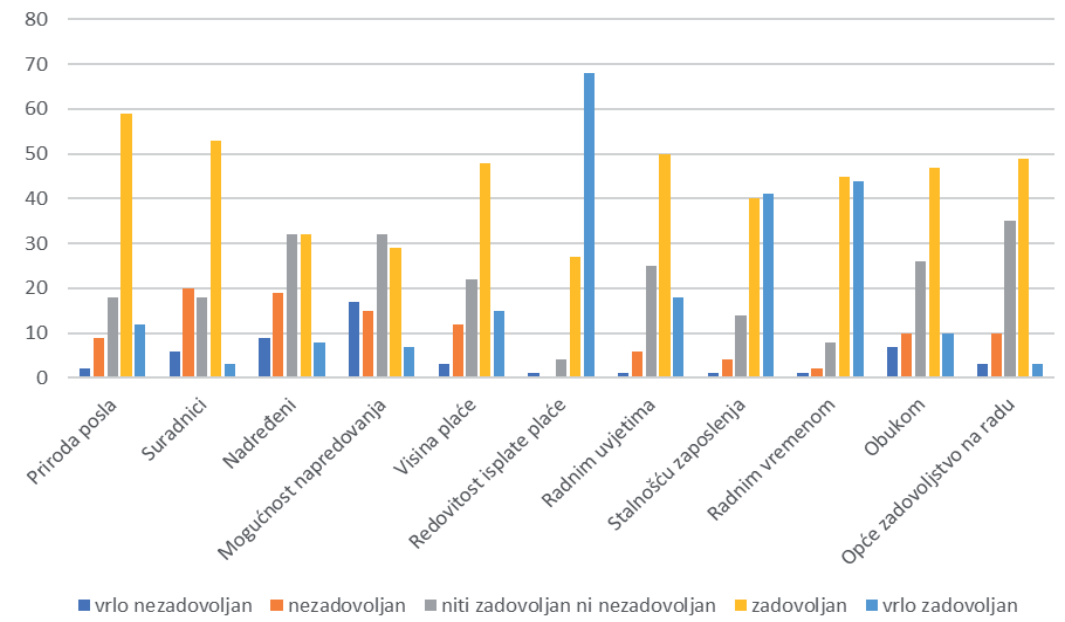


Raspodjela ocjena koja je prikazana na Grafikonu 2. ukazuje na to da su ispitanici vrlo zadovoljni s redovitošću isplate plaće, stalnošću zaposlenja i radnim vremenom, dok su najmanje zadovoljni nadređenima i mogućnošću napredovanja. U svrhu daljnje evaluacije prikupljenih podataka te potvrde mišljenja kreiranog na temelju podataka i grafičkog prikaza raspodjele rezultata zadovoljstva elementima posla, izračunata je prosječna ocjena svakog pojedinog elementa zadovoljstva posla ovog istraživanja.

Najvišu prosječnu ocjenu dobila je redovitost isplate plaće $(4,61)$, slijede zadovoljstvo radnim vremenom $(4,29)$ te stalnost zaposlenja $(4,16)$. U grupu elementa posla ocijenjenih srednjom ocjenom spadaju radni uvjeti $(3,78)$, priroda posla $(3,70)$ te visina plaće $(3,60)$. Slijede obuka $(3,43)$, suradnici $(3,27)$ i nadređeni $(3,11)$. Ispitanici su najmanje zadovoljni mogućnošću napredovanja te su tom elementu dodijelili najmanju ocjenu (2,94). Opće zadovoljstvo na radu ispitanici su ocijenili srednjom ocjenom $(3,39)$. Pregled prosječnih ocjena elemenata zadovoljstva poslom dan je u Tablici 6.

\section{Tablica 6. Prosječna ocjena zadovoljstva elementima posla}

\begin{tabular}{|lc|}
\hline Elementi posla & Prosječna ocjena \\
\hline Priroda posla & 3,70 \\
\hline Suradnici & 3,27 \\
\hline Nadređeni & 3,11 \\
\hline Mogućnost napredovanja & 2,94 \\
\hline Visina plaće & 3,60 \\
\hline Redovitost isplate plaće & 4,61 \\
\hline Radni uvjeti & 3,78 \\
\hline Stalnost zaposlenja & 4,16 \\
\hline Radno vrijeme & 4,29 \\
\hline Obuka & 3,43 \\
\hline Opće zadovoljstvo na radu & 3,39 \\
\hline
\end{tabular}

Izvor: Rad autora

Ne iznenađuje ocjena zadovoljstva zaposlenika redovitošću isplate plaće, radnim vremenom i stalnošću zaposlenja budući da se radi o poduzeću koje redovito podmiruje svoje obaveze, a prava radnika su dodatno regulirana kolektivnim ugovorom i u mnogim dijelovima su povoljnija od zakonom propisanog minimuma. Donekle iznenađuje činjenica da su ispitanici svoje suradnike i nadređene ocijenili srednjom ocjenom. Očito je došlo, dijelom i zbog izvanrednih i neuobičajenih uvjeta rada zbog primijenjenih epidemioloških mjera, do otuđenja i narušavanja međuljudskih odnosa. Ispitanici su najlošijom ocjenom vrednovali mogućnost napredovanja. Budući da najveći dio ispitanika pripada skupini sa srednjom stručnom spremom ( $53 \%$ ispitanika), a analizirajući interne akte poduzeća, postoji granica koju zaposlenici sa srednjom stručnom spremom mogu doseći te nakon toga ne postoji mogućnost daljnjeg napredovanja. U zadnjem dijelu ankete ispitanici su pozvani na samoprocjenu svog radnog učinka. Raspon ocjena radnog učinka je od 1 do 5, pri čemu ocjene imaju sljedeće značenje: 1 - ne zadovoljava, 2 - ispod prosjeka, 3 - prosječno, 4 - dobar i 5 - izuzetan. Samoprocjena radnog učinka prikazana je na Grafikonu 3. 


\section{Grafikon 3. Samoprocjena radnog učinka}

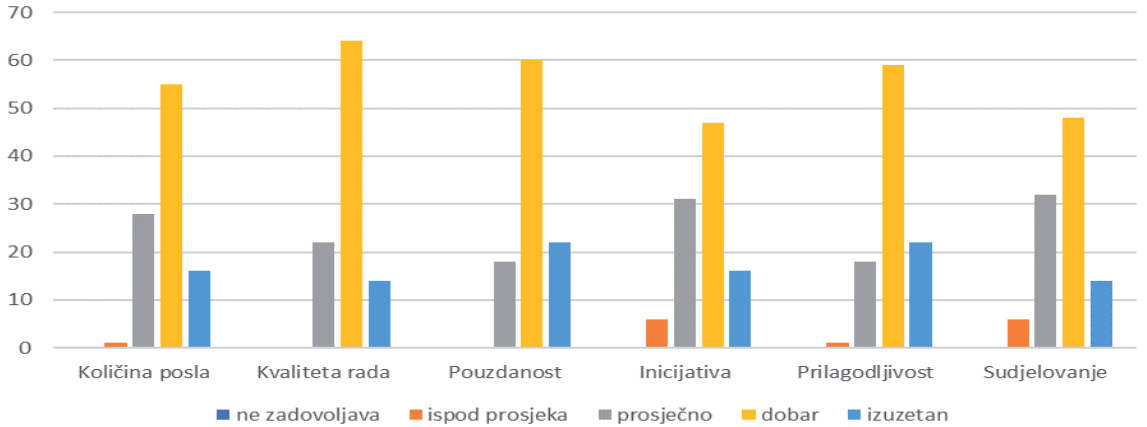

Izvor: Rad autora

Iz grafičkog prikaza uočava se da niti jedan ispitanik ni u jednom segmentu ocjenjivanja nije ocijenio svoj rad ocjenom „ne zadovoljava“. Također, može se uočiti da su sve kategorije radnog učinka ispitanici ocijenili najčešće ocjenom „dobar“.

U svrhu dodatne evaluacije rezultata istraživanja izračunata je i prosječna ocjena samoprocjene elemenata radnog učinka.

\section{Tablica 7. Prosječna ocjena elemenata radnog učinka}

\begin{tabular}{lc}
\hline Elementi radnog učinka & Prosječna ocjena \\
\hline Količina posla & 3,86 \\
\hline Kvaliteta rada & 3,92 \\
\hline Pouzdanost & 4,04 \\
\hline Inicijativa & 3,73 \\
\hline Prilagodljivost & 4,02 \\
\hline Sudjelovanje & 3,70 \\
\hline
\end{tabular}

Izvor: Rad autora

Ispitanici su svoj radni učinak ocijenili sljedećim ocjenama: pouzdanost $(4,04)$ i prilagodljivost $(4,02)$ su ocijenili najvišim ocjenama, zatim slijede kvaliteta rada $(3,92)$ i količina posla $(3,86)$, a najlošijim ocjenama su ocijenjeni inicijativa $(3,73)$ i sudjelovanje $(3,70)$. Budući da su u poduzeću česte promjene organizacije rada i poslovnih procesa, zaposlenici su se prisiljeni uvijek iznova prilagođavati novim okolnostima te su u tome postali vješti. Inicijativa je vrednovana relativno lošom ocjenom iz dva razloga: u nekim organizacijskim jedinicama rukovoditelji njeguju autokratski stil rukovođenja i jasno su određene procedure te nije dozvoljena nikakva inicijativa, dok u drugim slučajevima bilo kakva inicijativa znači novi radni zadatak pa zaposlenici izbjegavajući inicijativu izbjegavaju dodatne radne zadatke.

Sudjelovanje je od svih elemenata posla vrednovano najlošijom ocjenom. Budući da sudjelovanje podrazumijeva sposobnost za rad s drugima i za druge, u lošoj ocjeni ovog elementa mogu se prepoznati narušenost međuljudskih odnosa i nesklonost timskom radu.

Ukupna prosječna ocjena svih elemenata radnog učinka iznosi 3,87. 
Istovremeno s anketom provedeni su intervjui s menadžerima promatranog poduzeća. Intervjuirano je ukupno 8 menadžera. S obzirom na organizacijsku strukturu te dodijeljene ovlasti, u promatranom poduzeću postoje tri nivoa menadžmenta: visoki, srednji i niži menadžment. $U$ intervjuu su sudjelovala dva ispitanika visokog menadžmenta, tri ispitanika srednjeg menadžmenta i tri ispitanika nižeg menadžmenta. Od intervjuiranih menadžera, samo jedan ispitanik je prošao neki oblik dodatne edukacije koja se odnosila na rukovođenje ili motivaciju.

Zajedničko stajalište svih intervjuiranih menadžera je da sustav nagrađivanja nije adekvatan iz nekoliko razloga. Plaća i beneficije su regulirane i unaprijed definirane kolektivnim ugovorom i internim pravilnicima. Time su, bez obzira na rezultate rada, svima zajamčene plaća i sve ugovorene beneficije. Menadžeri uglavnom smatraju da bi sustav plaća trebalo izmijeniti na način da se odredi fiksna plaća, ali i da postoji mogućnost stimulativnog dijela plaće koji bi oni samostalno mogli odrediti ovisno o rezultatima rada svakog pojedinog zaposlenika.

Nadalje, menadžeri ističu da je proces napredovanja i razvoja karijere izuzetno spor i neefikasan. lako postoji mogućnost predlaganja premještaja zaposlenika, izuzetno se dugo čeka donošenje odluke na najvišoj razini, a ponekad se odluka niti ne usvoji. U promatranom poduzeću, upravo zbog sporosti sustava te nemogućnosti razvoja i napredovanja, u posljednje vrijeme uočena je fluktuacija zaposlenika, a što je do prije nekoliko godina bio iznimno rijedak slučaj.

U promatranom poduzeću ne postoji mogućnost destimulativnih mjera u smislu umanjenja osnovne plaće. Ako se neki zaposlenik neadekvatno ponaša, eventualno mu se dodjeljuju manje poželjni zadaci te ga se ne upućuje na terenski rad, pa samim time ne ostvaruje dnevnicu, pripravnost ni prekovremeni rad, a što se u konačnici odrazi na njegove primitke. Plaća i beneficije su većini radnika vrlo bitan faktor zadovoljstva radom.

Menadžeri često primjenjuju nematerijalne metode motivacije, kao što su pohvala, priznanje, poticanje kreativnosti i samoinicijative, mogućnost sudjelovanja i predlaganja. $\mathrm{Na}$ taj način stvara se pozitivna atmosfera i zaposlenici su motiviraniji za posao. Menadžeri dodatno ističu da sve materijalne kompenzacije imaju relativno kratko vrijeme pozitivan efekt te nakon proteka određenog vremena ponovo dolazi do pada motivacije. Kao općenitu ocjenu učinka poduzetih metoda motivacije zaposlenika, menadžeri ocjenjuju da su zaposlenici uglavnom motivirani i zadovoljni, no da još uvijek ima prostora za poboljšanje sustava u cjelini. Vezano uz radni učinak zaposlenika, svi menadžeri su radni učinak zaposlenika kojima rukovode uglavnom ocijenili s prosječnom ocjenom vrlo dobar.

Nakon provedenog istraživanja i analize prikupljenih podataka i informacija, dobiveni su rezultati koji upućuju na činjenicu da sustav motivacije u promatranom poduzeću nije u skladu sa željama kako zaposlenika tako ni menadžera. Budući da su mnoga istraživanja potvrdila povezanost motivacije zaposlenika sa zadovoljstvom poslom, kao i radnim učinkom, u promatranom poduzeću bi trebalo ozbiljno pristupiti dubinskoj analizi motivacijskog sustava u cjelini. Usporedno bi trebalo uložiti napor te poraditi na edukaciji menadžmenta u području rukovođenja, a posebno motivacije. Dodatan napor trebalo bi uložiti u istraživanje razloga narušenih međuljudskih odnosa budući da je organizacijska klima izuzetno važan element zadovoljstva poslom, ali i radnog učinka. Usklađivanjem motivacijskog sustava i poboljšanjem međuljudskih odnosa ostvareni bi bili preduvjeti za veću radnu uspješnost poduzeća i ostvarivanje zacrtanih ciljeva. 
U svrhu optimizacije sustava motivacije, poduzeće bi svakako trebalo razmisliti o mogućnosti primjene sljedećih preporuka:

- sustav nagrađivanja prilagoditi zaposlenicima i menadžerima,

- $\quad$ model plaća izmijeniti na način da se odredi fiksni dio plaće, a menadžerima pruži mogućnost određivanja stimulativnog dijela plaće u ovisnosti o radnom učinku pojedinca,

- $\quad$ sustav napredovanja odnosno razvoja karijere učiniti fleksibilnijim, a sam proces ubrzati,

- $\quad$ razmotriti model po kojem će i zaposlenici neadekvatne stručne spreme, u slučaju kada se kroz višegodišnji rad kod poslodavca ističu znanjem, sposobnostima i zalaganjem, na temelju obrazloženog pisanog prijedloga direktora sektora nadležnog za područje rada u kojem zaposlenik radi, moći napredovati na radno mjesto čije formalne uvjete radnik ne ispunjava u cijelosti, uz uvjet da radnik u stvarnosti radi posao iz opisa poslova tog radnog mjesta,

- $\quad$ provesti edukacije za menadžere na temu rukovođenja, timskog rada, metoda motivacije i sličnog,

- $\quad$ provesti dubinsku analizu razloga narušenih međuljudskih odnosa te otkloniti eventualne izvore loše prakse.

Poduzimanjem navedenih aktivnosti poduzeće bi otklonilo nedostatke te optimiziralo sustav u cjelini.

\section{ZAKLJUČAK}

Ljudski resursi predstavljaju ključne resurse svakog poduzeća. Motivirani i zadovoljni ljudski resursi su jednostavno conditio sine qua non uspješnog poduzeća. U ovom radu dan je kratki pregled teorijskih osnova motivacije, zadovoljstva poslom i radnog učinka zaposlenika kako bi se lakše razumjelo ljudsko ponašanje, posebno u kontekstu radnog okruženja. U skladu s temom rada, provedeno je istraživanje na primjeru odabranog poduzeća. Cilj istraživanja bio je utvrditi koji faktori motivacije i zadovoljstva poslom najviše doprinose radnoj uspješnosti i u kolikoj mjeri to čine te procijeniti usklađenost motivacijskog sustava sa željama zaposlenika odabranog poduzeća. Dodatno, pokušalo se utvrditi razinu motiviranosti i zadovoljstva poslom zaposlenika odabranog poduzeća koristeći Herzbergovu dvofaktorsku teoriju te procijeniti usklađenost motivacijskog sustava odabranog poduzeća sa željama zaposlenika.

\section{IP 1. Kolika je razina motiviranosti i zadovoljstva poslom zaposlenika odabranog poduzeća?}

Prvo istraživačko pitanje odnosilo se na utvrđivanje razine motiviranosti i zadovoljstva poslom zaposlenika odabranog poduzeća. Analizom podataka utvrđeno je da većina zaposlenika smatra plaću i sigurnost posla najjačim motivatorima za rad. S obzirom na pandemiju i općenitu nesigurnost poslovanja te ukupan pad gospodarstva, ovakvi rezultati istraživanja motivacije su donekle bili i očekivani. S druge strane menadžeri i politika poduzeća 
su najslabije ocijenjeni kao motivatori. Menadžeri su ocijenjeni tako niskom ocjenom zato što menadžeri u promatranom poduzeću uglavnom nisu educirani za poslove rukovođenja, kao niti o metodama motivacije. Politika poduzeća je također vrlo slab motivator jer zaposlenici nisu u dovoljnoj mjeri ni na adekvatan način informirani o toj tematici. Povrh toga, poduzeće se bavi reguliranom djelatnošću pa je i poslovna politika određena i ograničena od strane regulatora.

Što se tiče analize zadovoljstva poslom, zaposlenici su najzadovoljniji redovitošću isplate plaće i stalnošću zaposlenja, a najnezadovoljniji mogućnošću napredovanja. Budući da promatrano poduzeće redovito podmiruje svoje obaveze, a prava radnika su dodatno regulirana kolektivnim ugovorom i u mnogim dijelovima su povoljnija od zakonom propisanog minimuma, rezultati istraživanja su u skladu s činjeničnim stanjem. Donekle iznenađuje činjenica da su ispitanici svoje suradnike i nadređene ocijenili srednjom ocjenom. Očito je došlo, dijelom i zbog izvanrednih i neuobičajenih uvjeta rada zbog primijenjenih epidemioloških mjera, do otuđenja i narušavanja međuljudskih odnosa. Ispitanici su najlošijom ocjenom ocijenili mogućnost napredovanja. Budući da najveći dio ispitanika pripada skupini sa srednjom stručnom spremom (53\% ispitanika), prema trenutno važećim internim aktima, ne postoji mogućnost daljnjeg napredovanja. Ova činjenica je prepoznata kao vrlo bitan izvor nezadovoljstva te bi se poduzeće trebalo intenzivno baviti pronalaženjem rješenja. Dodatan naglasak problematici daje i uočen porast fluktuacije zaposlenika.

Svoj radni učinak zaposlenici su ocijenili prosječnom ocjenom vrlo dobar $(3,87)$, a sličnu percepciju o ukupnom radnom učinku imaju i menadžeri koji su radni učinak podređenih zaposlenika također ocijenili ocjenom vrlo dobar. Može se zaključiti da se samoprocjena radnog učinka zaposlenika i ocjena menadžmenta o radnom učinku zaposlenika s kojima rukovode podudaraju te da postoji prostor za poboljšanje radnog učinka.

\section{IP 2. Je li i koliko je usklađen motivacijski sustav odabranog poduzeća sa željama zaposlenika}

Drugo istraživačko pitanje odnosilo se na uspoređivanje toga je li i koliko je usklađen motivacijski sustav odabranog poduzeća sa željama zaposlenika. Proučavanjem motivacijskog sustava u cjelini, prikupljanjem podataka putem ankete te putem intervjua s menadžerima prikupljene su dodatne bitne informacije o sustavu motiviranja te razini educiranosti. Istraživanje je pokazalo da motivacijski sustav nije u potpunosti usklađen sa željama zaposlenika (uključujući i menadžere) te su dane preporuke za poboljšanje sustava. Primjenom preporuka poduzeće bi moglo poboljšati i uskladiti svoj sustav motiviranja, postići veće zadovoljstvo zaposlenika i poboljšati radni učinak.

Dodatni doprinos ovom istraživačkom radu moglo bi dati istraživanje apsentizma na primjeru odabranog poduzeća. Naime, zbog uočene fluktuacije, prisutne pandemije, kao i narušenih odnosa, trebalo bi istražiti razloge i razmjere apsentizma, a kako bi se moglo učinkovitim metodama na temelju prikupljenih spoznaja djelovati na otklanjanje uzroka nezadovoljstva radnika i niske motivacije za prisustvovanje na poslu. Budući da je apsentizam izravno povezan s radnim učinkom, uz pomoć smjernica za poduzimanje aktivnosti za smanjenje apsentizma, izravno bi se moglo utjecati i na povećanje radnog učinka $s$ obzirom na to da postoji prostor za poboljšanje istoga. 


\title{
ANALYSIS OF MOTIVATION, JOB SATISFACTION AND EMPLOYEE PERFORMANCE ON THE EXAMPLE OF THE SELECTED COMPANY
}

\author{
Davorka Prahin, Profess. spec. oec. \\ Underground Gas Storage Ltd \\ Phone: +385 (0) 99/ 3124 201, e-mail: davorka.prahin@psp.hr \\ Prof. Ivica Katavić, PhD \\ European Business School Zagreb \\ Selska 119, Zagreb \\ Phone: +385 (0)99/ 3695 585, e-mail: ivica.katavic@ebus.hr
}

\begin{abstract}
Human resources are undoubtedly the key resources of every company and play an essential role in achieving the goals and success of the company as a whole. In this context, motivation, job satisfaction and work performance have been recognized as key concepts related to human resources, and they have been increasingly discussed recently. Numerous researches have been conducted on their mutual relationships and attempts made to define what motivates employees most and to identify the elements of job satisfaction that employees consider the most important. The research also attempts to investigate the impact of motivation and job satisfaction on employee performance. For the purposes of preparing this final paper, a survey was conducted through the means of a questionnaire and interview. The results of the research showed that the greatest motivation factors of employees are the salary and job security, while the best assessment was given to the elements of work named: the regularity of salary payments, working hours and the permanence of employment. In self-assessment of work performance, employees rated their reliability and adaptability best. Further analysis of the collected data and information revealed that the motivational system is not fully aligned with the wishes of either employees or management. It also indicated that in the field of tangible and intangible rewards, promotion process and education can be refined and improved to make the whole system as well-balanced andand effective as possible.
\end{abstract}

Keywords: motivation, job satisfaction, motivation factors, job satisfaction factors, job performance 


\section{LITERATURA}

1. Abbah, M. (2014). Employee Motivation: The Key to Effective Organizational Management in Nigeria. IOSR Journal of Business and Management, 16(4), 01-08. doi:10.9790/487X-16410108.

2. Bahtijarević Šiber, F. (1999). Management ljudskih potencijala. Zagreb: Golden marketing.

3. Brayfield, A. H. i Crockett, W. H. (1955). Employee attitudes and employee performance. Psychological Bulletin, 52(5), 396-424. doi:10.1037/h0045899.

4. Brnad, A., Stilin, A. i Tomljenović, Lj. (2016). Istraživanje motivacije i zadovoljstva zaposlenika u Republici Hrvatskoj. U S.Hirnig, E. Ribarić Čučković i M. Gligora Marković (ur.), Zbornik Veleučilišta u Rijeci, 4, 109-122. Rijeka, Veleučilište u Rijeci.

5. Brown, D. i McIntosh, S. (2003). Job satisfaction in the low wage service sector. Applied Economics, 35(10), 1241-1254. doi: 10.1080/00036840210150875.

6. Buble, M. (2006). Management. Split: Ekonomski fakultet Sveučilišta u Splitu.

7. Greenberg, J. i Baron, R. (1998). Ponašanje ljudi u organizacijama. Beograd: Želnid.

8. Herzberg, F. (1974). Motivation-Hygiene profiles: pinpointing what ails the organization. Organizational Dynamics, 3(2), 18-29. doi: 10.1016/0090-2616(74)90007-2.

9. Hrvatska enciklopedija. Motivacija. Preuzeto s https://www.enciklopedija.hr/natuknica. aspx?id=42115.

10. laffaldano, M. T. i Muchinsky, P. M. (1985). Job satisfaction and job performance: A metaanalysis. Psychological Bulletin, 97, 251-273. doi: 10.1037/0033-2909.97.2.251.

11. Judge, T. A., Thoresen, C. J., Bono, J. E. i Patton, G. K. (2001). The job satisfaction-job performance relationship: A qualitative and quantitative review. Psychological Bulletin, 127, 376-407. doi: 10.1037/0033-2909.127.3.376.

12. Locke, E. A. (1976). Personnel attitudes and motivation. Annual Review of Psychology, 26, 457480. doi: 10.1146/annurev.ps.26.020175.002325.

13. Obradović, V., Samardžija, J. i Jandrić, J. (2015). Menadžment ljudskih potencijala u poslovnoj praksi. Zagreb: Plejada d.o.o.

14. Petty, M. M., McGee, G. W. i Cavender, J.W. (1984). A meta-analysis of the relationship between individual job satisfaction and individual performance. Academy of Management Review, 9, 712-721. doi: /10.5465/amr.1984.4277608.

15. Rahimić, Z. (2010). Menadžment ljudskih resursa. Sarajevo: Ekonomski fakultet u Sarajevu.

16. Robbins, S. P. i Judge, T. A. (2009). Organizacijsko ponašanje, 12. izd., Zagreb: Mate d. o. o., Zagrebačka škola ekonomije i menadžmenta.

17. Tudor, G. (2010). Vođenje i motiviranje ljudi. Zagreb: M.E.P. d.o.o. 